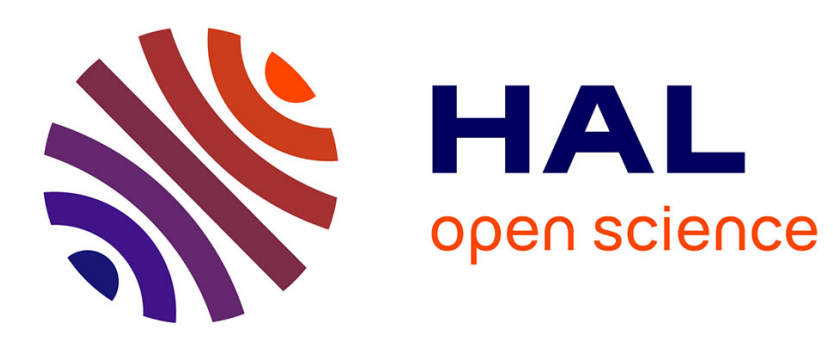

\title{
Issues and Methodologies in Coptic Palaeography
}

Anne Boud'Hors

\section{To cite this version:}

Anne Boud'Hors. Issues and Methodologies in Coptic Palaeography. The Oxford Handbook of Egyptian Epigraphy and Palaeography, 2020. halshs-03039992

\section{HAL Id: halshs-03039992 \\ https://shs.hal.science/halshs-03039992}

Submitted on 1 Sep 2021

HAL is a multi-disciplinary open access archive for the deposit and dissemination of scientific research documents, whether they are published or not. The documents may come from teaching and research institutions in France or abroad, or from public or private research centers.
L'archive ouverte pluridisciplinaire HAL, est destinée au dépôt et à la diffusion de documents scientifiques de niveau recherche, publiés ou non, émanant des établissements d'enseignement et de recherche français ou étrangers, des laboratoires publics ou privés. 


\section{Issues and Methodologies in Coptic Palaeography a}

Anne Boud'hors

The Oxford Handbook of Egyptian Epigraphy and Paleography

Edited by Vanessa Davies and Dimitri Laboury

Print Publication Date: Apr 2020 Subject: Archaeology, Egyptian Archaeology

Online Publication Date: Mar 2020 DOI: 10.1093/oxfordhb/9780190604653.013.47

\section{Abstract and Keywords}

Due to the drastic change of the graphic system that accompanied the emergence of the Coptic language and manuscripts (third century), the issues and methods in producing texts have also changed, becoming closer to those related to Greek texts copied and written in Egypt. The most difficult issue in Coptic codicology is assigning scripts a date, which is linked to their description. The article discusses in some detail these dating issues, first for literary manuscripts, taking into account the dialect and considering not only writing but also other parameters, such as the various aspects of copying and manufacturing a book or the provenance, and then for documents, where regional practices are important variables.

Keywords: codicology, Coptic, date, dialect, document, manuscript, script

AT the end of the third century, notwithstanding the fact that the detailed circumstances of the process remain unknown, the first Coptic manuscripts are emerging. Their language, the last step of Egyptian, appears fully fixed, although with various dialectal varieties, and their graphic system is standardized, after hesitations visible in the different texts called "Old Coptic," which are mostly attempts to transcribe Egyptian in Greek letters (Quaegebeur 1982; Satzinger 1991). This system uses the twenty-four letters of the Greek alphabet supplemented on the one hand by six signs (or seven for some dialects) borrowed from Demotic and corresponding to sounds unknown in Greek (Figure IV.8.1): $\underline{w} / \bar{s} /, \mathrm{q} / f /, \mathrm{\imath} / \mathrm{h} /, \mathrm{z} / \mathrm{x} /, \mathrm{b} / \mathrm{x} /, \mathrm{x} / \mathrm{c} /, \mathrm{\sigma} / \mathrm{ky} /,+/ \mathrm{ti} /$, and on the other hand by a syllabic superlinear marking. A notable exception to this system is provided by the Papyrus Bodmer VI, a copy of the book of Proverbs written in a peculiar dialectal variety (dialect $\mathrm{P}$ ), which uses several Demotic signs not included in the Coptic script, while the syntax is fully Coptic (Kasser 1960).

The production of texts written in Coptic extends from the end of the third century to the late nineteenth. Two categories are traditionally distinguished: (1) literary texts, Christian or para Christian in content, translated from Greek or composed in Coptic, transmitted through books copied in intellectual circles, mostly monastic; (2) nonliterary texts, or 
documents, copied for a single occasion on various materials (papyrus, parchment, and paper as well as shards of clay and limestone chips called "ostraca"): these are legal documents, accounts, letters. The period considered here will not exceed the twelfth century, which is roughly both when Coptic completely ceased to be used in documents, as the result of the Arabization that began in the late seventh century, and when the great monastic libraries started declining.

(p. 619) Coptic manuscripts, however, are rarely associated with an archaeological context and are often deprived of absolute dating. Thus the main challenge of palaeography is to overcome this lack, trying to place in time and space a witness detached from its original environment (Kasser 1991b). It is a still underdeveloped and inexact discipline, the task being complicated by the fragmented state of the documentation, the diversity of textual genres and dialects, and the multiplicity of materials as well as the conservatism of the scribes and copyists. It can rely to some extent on the comparison with Greek manuscripts produced in Egypt, especially in the period before the Arab conquest. It also shares several issues with the study of Oriental manuscripts. Other important questions related to social phenomena are also at stake in Coptic palaeography, namely, the existence and organization of writing centers (scriptoria) or the modalities of learning.

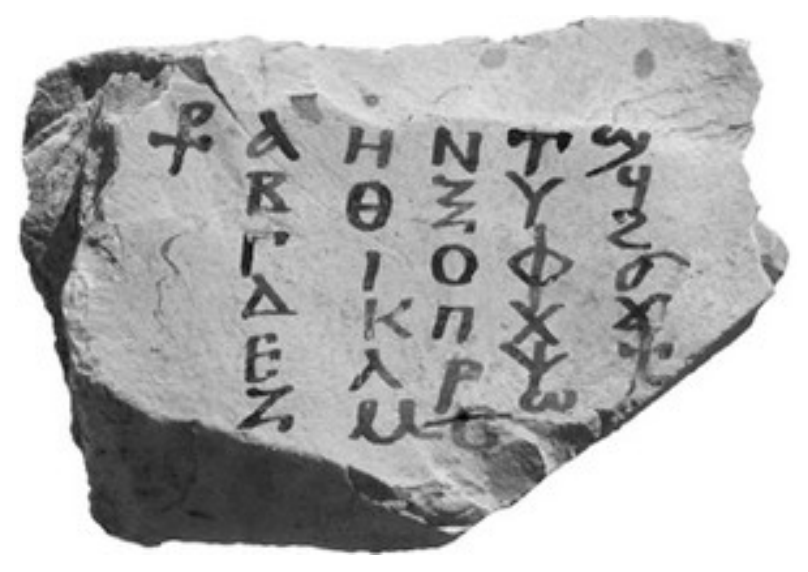

Figure IV.8.1. A limestone ostracon with a Coptic alphabet (Thebes, seventh to eighth century). The Greek letters are on the first four columns and the Egyptian ones on the fifth. O. Frange 480, TT 29 inv. 292414. (C) Université Libre de Bruxelles, Brussels.

\section{To Date or Not to Date (?)}

The vast majority of Coptic manuscripts are not dated in an absolute way. Literary manuscripts started bearing dates only from the ninth century onward, when the practice of adding a colophon at the end of a manuscript, that is, a set of indications about the copyist and his book, became usual. The oldest dated manuscript comes from the Fayyum: it is just prior to 823, the date of donation mentioned in the colophon (van Lantschoot 1929, $\left.\mathrm{n}^{\circ} \mathrm{I}\right)$. Documentary texts are also rarely dated, except for certain legal texts. More often, 


\section{Issues and Methodologies in Coptic Palaeography}

they have a relative date, referring to tax unities of fifteen years called "indictions" (the date is given for the " $n$ year of the indiction"). Therefore, the question of dating has mobilized scholars since the nineteenth century. A quick overview of the different methods and attitudes toward this problem is instructive.

(p. 620) The first catalog of manuscripts was compiled by the Danish scholar Georg Zoëga ([1810] 1973). Its aim was to describe and classify thousands of parchment sheets and fragments written in Sahidic Coptic. At that time, their origin was unknown, but at the end of the nineteenth century, they would prove to be remains of the great library of the so-called White Monastery or Monastery of Shenoute in Upper Egypt. Zoëga was able to distinguish nine types of writing (Latin classes), which he classified from I to IX in a chronological perspective without assigning dates for the different types, but giving copies at the end of the catalog. The principles of this work, pioneering in every respect (for a more detailed presentation, see Buzi 2015), were followed by all scholars working on the remains of the same library in the late nineteenth and early twentieth centuries.

The Album de paléographie copte by Henry Hyvernat ([1888] 1972) has met an enduring success. Although not accompanied by any analysis, it provides photographic reproductions and short notices of a large number of manuscripts dated or assigned to the sixth through eighteenth centuries. That it does not contain examples of manuscripts older than the sixth century is due to the fact that most of the ancient Coptic manuscripts have appeared in the second half of the twentieth century.

It is worth quoting in full the title of the book by Stegemann (1936): Koptische Paläographie: 25 Tafeln zur Veranschaulichung der Schreibstile koptischer Schriftdenkmäler auf Papyrus, Pergament und Papier für die Zeit des III.-XIV. Jahrhunderts; Mit einem Versuch einer Stilgeschichte der koptischen Schrift (Coptic Palaeography: 25 Plates Illustrating the Writing Styles of Coptic Written Records on Papyrus, Parchment, and Paper for the Period of the III-XIV Centuries; With an attempt at a stylistic history of Coptic writing). This programmatic title covers indeed the largest attempt in terms of history of writing (third through fourteenth centuries). Both literary (Buchschrift) and documentary handwritings (Urkundenschrift) are taken into account, according to well-defined periods. The study concerns both the individual shapes of the letters and the general appearance of the writing, thanks to hand copies, on the basis of the largest possible number of dated witnesses. This is the only book that had the ambition to handle all of the handwritten documentation. Nevertheless, the extreme "systematization" of the book, its austerity (German written in Gothic letters), and the small number of photographic plates, may have discouraged many researchers from making it their reference. Nowadays only a few scholars-mostly German-cite and use it, which is unfortunate because the materials gathered and the issues raised therein remain relevant.

The book titled Koptische Paläographie (Cramer 1964) is generally overlooked. It is based on an individual analysis of the shape of each letter through the centuries (fourth to sixteenth), without giving clear criteria for the proposed dates. However, the collection of reproductions it provides can be of some use. 
It therefore appears that the attempts to build a reasoned Coptic palaeography have proved unsuccessful. Throughout the twentieth century, a skeptical attitude has prevailed. As a result, the descriptions of manuscripts are mostly devoid of dates. On the other hand, efforts have focused on the description of the scripts.

\section{(p. 621) To Describe and to Date: Between Types and Periods}

\section{Different Terminologies}

The descriptive terminology of Coptic writings varies from one description to another, with significant differences in appreciation and dating. The system proposed by Layton (1987) mentions the degree of inclination of the writing, the presence of thick and thin strokes, and the characteristic shape of certain letters. These criteria are used to distinguish between two major types of upright scripts: one where all the letters have about the same frame, virtually fitting a sort of square, the other generally thin, where a contrast between wide and narrow letters can be observed. To these two types some scholars give the respective designations of "unimodular" and "bimodular," coined by G. Cavallo (Emmel 2004) as an alternative to traditional terminology inherited from the Greek paleography, where they are called "biblical majuscule" and "Alexandrian majuscule" (Cavallo 1967; Irigoin 1959). Around the time when Greek manuscripts of the Byzantine world started to be copied with a minuscule script (ninth to tenth centuries), Coptic copyists continued to use a majuscule, both unimodular and bimodular. As for the latter, they adopted specific features, including a certain flattening and stiffness of certain characters, as well as ink dots at the end of the letters. Table IV.8.1 tries to give an idea of the equivalences between the different terms in use.

\begin{tabular}{|c|c|c|}
\hline Layton 1987 & $\begin{array}{l}\text { Emmel } \\
2004\end{array}$ & Traditional \\
\hline $\begin{array}{l}\text { Upright, thick-and-thin style, } \\
\text { wide } \epsilon, \mathrm{O}, \mathrm{c}, 3 \text { or } 4 \text {-stroke } \mu\end{array}$ & $\begin{array}{l}\text { unimodu- } \\
\text { lar }\end{array}$ & $\begin{array}{l}\text { Biblical majus- } \\
\text { cule }\end{array}$ \\
\hline Upright, narrow $\epsilon, 0, c, 3$-stroke $\mu$ & bimodular & $\begin{array}{l}\text { Alexandrian ma- } \\
\text { juscule } \\
\text { Coptic majuscule }\end{array}$ \\
\hline (Right-)sloping majuscule & & $\begin{array}{l}\text { (Right-)sloping } \\
\text { majuscule }\end{array}$ \\
\hline
\end{tabular}




\section{Types and Periods}

These types can be matched with periods of time as shown in Table IV.8.2, which is inspired by a recently proposed classification for "canonized" scripts in early Greek manuscripts (Orsini and Clarysse 2012). It should be added to the types mentioned earlier an upright and thin majuscule, only found in papyri of the earliest period. Such a periodization remains rough, as several types of writing are used at the same time, especially the biblical majuscule, which has a long history, and even within the same (p.622) manuscript. This latter phenomenon is known as the use of "distinctive" scripts. For example, a manuscript copied in unimodular majuscule may include section titles in bimodular majuscule, while the final annotations of the copyist (colophons) are generally written in sloping majuscule (Figure IV.8.2.).

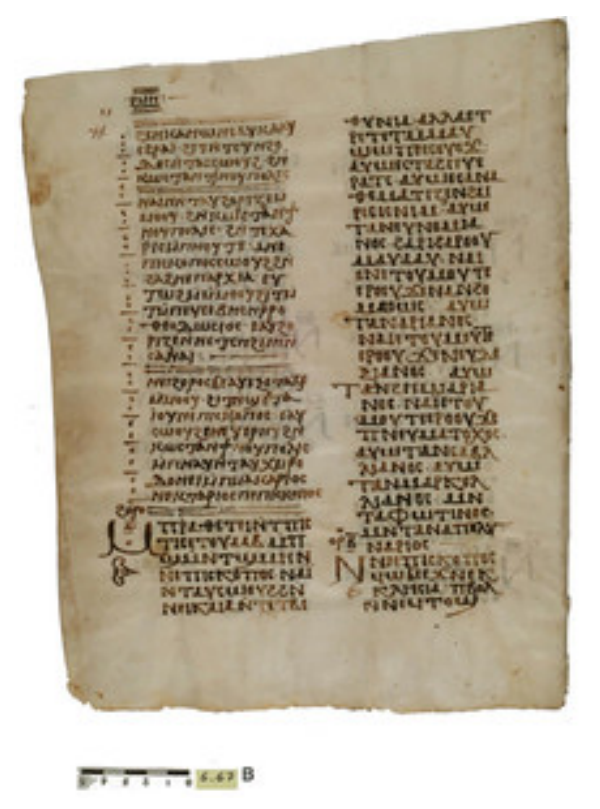

Figure IV.8.2. A leaf of a manuscript with a Coptic translation of the Acta Conciliorum (White Monastery, tenth to eleventh century). The text is copied in Coptic majuscule, while the introductive sections are in sloping majuscule. IFAO, Copte 067v. (C) Institut français d'archéologie orientale, Cairo. 


\section{Table IV.8.2.}

\begin{tabular}{|c|c|c|c|}
\hline Туре & Period & Literary & $\begin{array}{l}\text { Docu- } \\
\text { mentary }\end{array}$ \\
\hline $\begin{array}{l}\text { Upright and thin majus- } \\
\text { cule (severe style); pa- } \\
\text { pyrus }\end{array}$ & fourth & $\mathrm{X}$ & $\mathrm{X}$ \\
\hline Biblical majuscule & $\begin{array}{l}\text { fourth } \\
\text { through } \\
\text { tenth }\end{array}$ & $\mathrm{X}$ & $\begin{array}{l}\text { Occasion- } \\
\text { ally }\end{array}$ \\
\hline Alexandrian majuscule & $\begin{array}{l}\text { sixth } \\
\text { through } \\
\text { tenth }\end{array}$ & $\mathrm{X}$ & $\begin{array}{l}\text { Occasion- } \\
\text { ally }\end{array}$ \\
\hline Coptic majuscule & $\begin{array}{l}\text { ninth } \\
\text { through } \\
\text { twelfth }\end{array}$ & $\mathrm{X}$ & ------ \\
\hline Sloping majuscule & $\begin{array}{l}\text { fourth } \\
\text { through } \\
\text { twelfth }\end{array}$ & $\begin{array}{l}\text { X, especial- } \\
\text { ly after the } \\
\text { ninth cen- } \\
\text { tury and as } \\
\text { "distinc- } \\
\text { tive" script }\end{array}$ & $\mathrm{X}$ \\
\hline
\end{tabular}

\section{Resorting to Codicology}

\section{Paleography and Codicology: A Comprehensive Approach}

From the 1980s, emphasis was placed on the necessity to take into account not only the writing of a manuscript but also all its material aspects, according to the habits of catalogs of Greek manuscripts (Layton 1985). Such aspects include the materials, dimensions, layout (text written in full page or in columns), and organization of the quires. These principles have been implemented in many catalogs (Layton 1987; Depuydt 1993; Emmel 2004). Moreover, reports on Coptic palaeography presented since then to the Coptic Studies Congress always consider palaeography and codicology together (Emmel 1993, 1999; Boud'hors 2006; Torallas Tovar 2016). Nevertheless, a handbook is still a desideratum. 
This comprehensive approach allows us to propose three stages in the production of Coptic manuscripts, based on the tools and indications available.

\section{Three Main Phases}

In the ancient period (fourth to sixth century), the scripts are indeed already diverse. However, the comparison with the more or less contemporary Greek manuscripts is (p. 623) (p. 624) suitable. Besides, codicological features such as relatively small dimensions, lack of ornamentation, and copy in full page form a relevant set of data. Dating is more or less precise depending on the case. For example, the Greek and Coptic writings from the collection called "Papyrus Bodmer," which includes manuscripts in both languages written on papyrus and parchment, most of them datable to the fourth century, have been used for refined typological and qualitative comparisons (Orsini 2015). Coptic books of papyrus containing Gnostic texts, discovered at Nag Hammadi (Upper Egypt), still have their bindings, which contain fragments of documentary texts from the midfourth century that were recycled as stuffing material. These documents confirm the dating of the manuscripts themselves to a slightly later period. Conversely, the manuscripts can be used as a reference for other manuscripts displaying the same kind of characteristics.

From the second half of the ninth century onward, the existence of colophons and dated manuscripts, even though they are not the majority, facilitates comparisons. The manuscripts usually have larger dimensions and are copied in two columns. They mostly come from two great monastic libraries, namely, the monastery of Shenoute in Upper Egypt and the monastery of Saint-Michael in Fayyum. The latter ones, discovered in 1910, have significantly enriched the documentation in comparison with the first Album de paléographie (Hyvernat [1888] 1972). As for the White Monastery, where the manuscripts were found in a very fragmentary state, it is not rare to find an isolated leaf bearing a colophon, without being able to relate it to a manuscript. Although much remains to be done in reconstructing the books and classifying the many scripts in use at this time, substantial progress is also being achieved, particularly in the identification of individual hands (Suciu 2011, 2014).

Between these two extremes lies a particularly vague period, when comparisons with the Greek witnesses are no longer relevant, while palaeographic and codicological indications are not sufficiently decisive. To control the great fantasy in the dating proposals for manuscripts from this period, or at least to reduce the margins of uncertainty, other approaches should be considered, the provenance of manuscripts being one of them. 


\section{Paleography and Dialects: The Relevance of the Diacritical Signs}

\section{Various Types of Signs}

Among the codicological aspects mentioned thus far, the signs deserve special attention. Coptic manuscripts contain a variable amount of diacritics, which are described in (p. 625) more or less detail according to catalogs and text editors. Some are inherited from the practice of Greek manuscripts and concern the organization of the text, either as the equivalent of a logical punctuation (dot or set of dots) or as the marking of paragraphs or sections (paragraphus, coronis, diple) (Layton 1987), with a variously developed ornamentation (Jansma 1973). Others are a superlinear marking of the letters that is part of the graphic system of Coptic. This is a syllabic marking unparalleled in Greek, a language where every syllable is vocalized. In Coptic, where only the stressed syllables are vocalized, the superlinear marking is used to transcribe the vocalization (/e/) of an unstressed syllable. Its use is optional and rarely systematic. It can take various forms and positions, according to copyists and above all to dialects. Finally, other signs adopting various forms (dots, apostrophes), function as separators of syllables, grammatical elements, or accentual units. The use of the latter varies considerably from one manuscript to another and even within a manuscript.

\section{Manuscripts and Dialects}

Generally, palaeographic studies do not consider dialects and concern implicitly manuscripts and documents written in Sahidic (S), a neutral dialect that was from the fourth until around the eleventh century the main literary and common language of the Nile Valley. As the literature in this dialect is by far the most massive, it has monopolized the attention of scholars.

Bohairic, the other main literary Coptic dialect, was used in northern Egypt as early as the fourth century and became from the eleventh century the official language of the Coptic Church, still being its liturgical language nowadays. A few manuscripts in this dialect are generally included in the palaeographic albums. The majority of witnesses to the period between the ninth and thirteenth centuries are in fact written in biblical majuscule, with use of various distinctive scripts for paratextual information (titles, colophons), as in Sahidic manuscripts, the most visible difference being the use of an additional letter (b) exclusive to this dialect. Thereafter, the writing of Bohairic manuscripts evolved, until the nineteenth century, toward more flexibility and differentiation in the module and the line of the letters. For this period, which is beyond the framework established for this article, there are no studies. On the other hand, several witnesses to the early period (fourth-fifth centuries) have appeared in the second half of the twentieth century, as well as a large number of seventh century epigraphic inscriptions from the Kellia, a monastic site in Lower Egypt. A general study of Bohairic paleography would be therefore desirable. 
The only "minor" dialect that survived until the tenth century is the Fayyumic. Some literary witnesses to this dialect display peculiar shapes of certain letters borrowed from Demotic $(\underline{w}, 2,6)$. Although not as spectacular as the peculiarities of P.Bodmer VI, these differences allow the careful observer to identify a Fayyumic manuscript (Andersen, Holmen, and Tait 1999). Conversely, in the rare cases where a witness of this dialect (p. 626) does not have these features, one can wonder whether it is the product of a particular scriptorium, where practices were different.

In the ancient period (fourth-sixth centuries), several other literary dialects were in use. There are only a few palaeographic differences to be observed from one dialect to another, except for the diacritic signs, which should thus not be neglected. Nevertheless, some scholars do not reproduce them at all in their editions, considering that the superlinear marking was used as a reading aid in a text written without word division (scriptio contin$u a)$, but has no reason to be in a text where the words are separated. This is only acceptable if a description of the system is provided.

\section{Superlinear Signs and Dialects}

In the standard use of Sahidic manuscripts (Layton 2000, §38), a superlinear stroke is put above the consonants $\mathrm{M}, \mathrm{N}, \mathrm{P}$ either when they are grammatical elements (preposition, genitive marker, negation, and verb in the case of $p$ ) or at the beginning of a word before another consonant ( $\overline{\mathrm{N} T O K}, \overline{\mathrm{M} M O N}$ ); it is placed above two consecutive consonants that form an unstressed syllable, as a "connective stroke" ( $\overline{2 \mathrm{~N},} \mathrm{NTK}, \mathrm{TH} \overline{\mathrm{Pq}} \overline{)}$; in addition, it is often to be found on the syllable I, where it looks like a little curve, as well as on interrogative oy and the Greek particle H. A consonantal /i/ is usually marked by a diaeresis.

In Bohairic manuscripts, the superlinear mark is closer to a dot. It is called djinkim, a Coptic word that means a movable "vowel sign," coined by medieval Coptic grammars based on the categories of Arabic grammar. Two successive systems have been identified, of which only the first fits the period considered here: "The old-style system, which is thought to have prevailed until about $1400 \mathrm{CE}$, marks only (1) single vowels forming a syl-

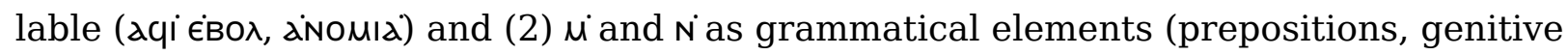
marker, negation), and at the beginning of a word, before another consonant ( $P \in M$ MXXHMI, MaNicuN2, MiTON, Niok)" (Polotsky 1949). The same type of system exists in manuscripts of the Middle Egyptian dialect (M; see the details of these systems in Kasser 1991a).

Practices seem to vary in the Fayyumic manuscripts, even though they have not been systematically studied. Some have no marking at all; others display a system similar to the Sahidic one, but with short strokes in place of diaeresis, whereas a third category has a sporadic marking, which borrows from several systems. Studying these markings could contribute to the identification of different copy centers.

Northern systems (B and M) were not without influence on Sahidic manuscripts. In the scriptorium of Touton, in the Fayyum, the superlinear marking of the manuscripts dated to the ninth and tenth centuries can be defined as a combination between the standard Sahidic system and the late Bohairic one (djinkim above a vowel forming a syllable, on the 
first of two consonants beginning a word, on the prefix of Present I, on the definite article, and on the monosyllabic verb $\underline{w}$ ). As the manuscripts copied in this scriptorium were sent to various monasteries, including the White Monastery in Upper Egypt, the identification of such a superlinear system is valuable to define the origin and possible date of a fragment (Nakano 2006).

\section{(p. 627) Provenance and Date: The Case of the Bib- lical Majuscule}

A recent comprehensive study can be seen as an attempt to return to a strict Coptic palaeography, exclusively considering the shape and thickness of the letters (Orsini 2008). In the line of the work on the biblical majuscule (Cavallo 1967), it follows a division into four major phases. The final phase, to which many Coptic manuscripts belong, extends from the sixth to the second half of the ninth century, a period of "decline" of this writing, with a gradual mannerism. According to the author, until the beginning of the sixth century, there would be no chronological discrepancy between Greek and Coptic manuscripts; only after this period would Coptic scripts have their own development. This study faces two important challenges. First, it sticks to biblical manuscripts, while this type of writing has been used for many other types of text, including the works of the great monastic writer Shenoute. Second, it takes no account of the dating issues related to the provenance of the manuscripts. For example, the vast majority of sheets and fragments from the White Monastery are generally thought to have been copied in a period between the ninth and twelfth centuries. This is certainly a too short period, as codicological characteristics of several fragments point to an earlier date. However, it is not reasonable to assign a White Monastery fragment, such as Louvre E 9985 (among others), to the late fifth century on the basis of the script, without going a little bit in this discussion about the library and without taking into account the size, diacritics, and decoration.

Considering the provenance of the manuscripts can also elucidate regional practices. This is well illustrated by the case of manuscripts copied in the Theban region (western bank of the Nile at Luxor; Boud'hors 2008). Almost all the witnesses of the book production there are written on papyrus, many of them in biblical majuscule. While the study of the writing itself would do little to refine dating, we know that the monastic institutions of the region were active from the very end of the sixth until the late eighth century. In the absence of further data, one must be content with this range. Moreover, codicological features of these manuscripts are fairly uniform and can help locate other fragments whose provenance is unknown. Finally, despite the lack of colophons, many copyists are known by their correspondence. The Theban region is the place par excellence where literary and documentary handwritings coexist. 


\section{Documentary Scripts}

\section{Description and Dating}

The problems posed by Coptic documentary palaeography (about seven thousand texts) have been formulated by Alain Delattre (2007): on the one hand, there are too few (p. 628) dated texts, which makes it impossible to establish a chronology of writing types, and on the other hand, the variety of scripts at a given time is wide. Besides, specific tools, such as albums or registers, are lacking, photographs in publications, especially the oldest ones, are not always satisfactory, and access to digital images is not yet sufficient. Thus, the description and dating of Coptic documents is still largely left to the subjectivity of the publisher.

An important distinction in the field of documentary texts, as opposed to literary manuscripts, which are almost always written by professional copyists, can be established between professional hands (notaries, public writers, professors) and nonprofessional hands (semiliterate, students, casual writers), the latter, which occur mostly in the letters, being almost impossible to categorize and date.

\section{Descriptive Criteria}

Several criteria are taken into account in the description of documentary Coptic writings, namely, inclination (usually right), cursivity (the more cursive a writing is, the more ligatures there are between letters, on the model of Greek writings), and the rather (p. 629) bilinear or quadrilinear aspect: a writing is termed bilinear when the letters are contained between two imaginary lines, so all letters being roughly the same size (as in a majuscule); it is called quadrilinear when the height of the letters is spread on four imaginary lines, vertical strokes of some letters rising or falling until the extreme lines (comparable to a minuscule) (Figure IV.8.3).

As for dating, the opposition between majuscule or bilinear and minuscule or quadrilinear is the most relevant. "Until the sixth century, all Coptic texts are written in 'majuscule,' more or less cursive. Then, in the seventh and eighth centuries, the two types of writing coexist. The 'minuscule' scripts are primarily attested in the eighth century. From the ninth century onwards, only a majuscule survives, as a bilinear calligraphy of the quadrilinear scripts" (Delattre 2007). 


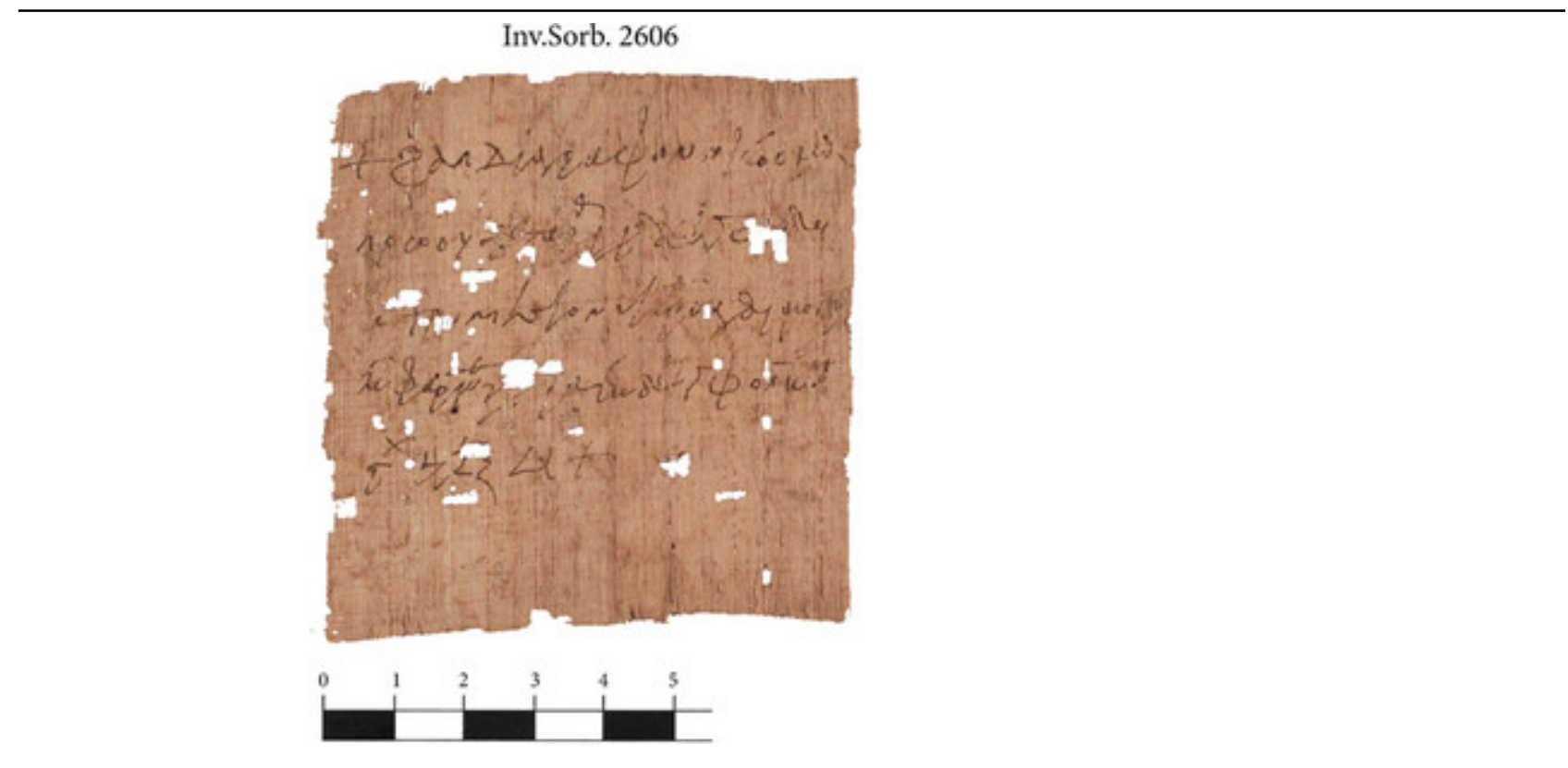

Figure IV.8.3. A tax receipt (eighth century, Middle Egypt). The script is minuscule and cursive. Inv.Sorb. 2606. (c) Université Paris-Sorbonne-Institut de Papyrologie, Paris.

\section{Some Steps in the Development of Coptic Documents}

Coptic documents from the archaic period (fourth century) were relatively few before the excavation of the site of Kellis (Dakhla oasis) at the end of the twentieth century that provided the library and correspondence of a Manichean community. These letters expand the range of types of writing known to that time. They are indeed using a majuscule script, but with various degrees of inclination and cursivity (Gardner and Choat 2004). Moreover, there are several examples of one and the same hand used to write letters from different senders, which shows the possible existence of scribal workshops even then in the Nile Valley.

Another set of documents that can be assigned to a delimited period of time is the bilingual (Greek and Coptic) archive of Dioscorus, poet and notary in the village called Aphrodite (Upper Egypt) during the sixth century. Greek papyri from the archive, whose study began long ago, provide good support to contextualize and date the Coptic pieces, currently under study (Vanderheyden 2012). Here again, different types of majuscule scripts coexist. This period can be considered as a kind of transition, as some writings are still quite upright and archaic, while regularly right-sloping hands, including Dioscorus's hand itself, are already announcing types common in the seventh century (MacCoull 1997).

The seventh and eighth centuries are the most complex period, when the documents are the most numerous, since at that time Coptic began to compete with Greek in the administration, a development that would slowly be dried up by the Arabization subsequent to the conquest of 641. Archaeological or historical data are lacking most of the time. In- 
deed, the Theban region provides papyri and ostraca with typical handwritings, namely, regularly right-sloping majuscules, for which a point of origin around the beginning of the seventh century is guaranteed by the presence of a date, thanks to the mention of a sun eclipse assignable to 601 on one of the ostraca (Gilmore and Ray 2006). However, looking at the examples given in Table 11 of Stegemann (1936), it is clear that this type of writing is still attested in a document dated to 732, while another document, dated 709 and coming from Aphrodito, is written in a very cursive minuscule. In fact, the two documents come from quite different backgrounds, one being a donation made (p. 630) to a monastery, the other part of the local administrative archive, directly dependent on the central government. Again, social and regional considerations are proving important.

In the ninth century, there was a return to majuscule scripts, especially in documents from Middle Egypt and Fayyum. They differ from the previous by the presence of small strokes or dots at the ends of some letters, which gives them a mannered appearance. Finally, in the later period (ninth to tenth centuries), letters are written on papyrus and paper in very cursive writings, sometimes almost illegible (most of the texts are still unpublished; see Crum 1905, pl. 15, n²1214).

\section{Specificities of Documentary Palaeography}

\section{Hands and Styles}

Professional scribes can vary their styles. What has been defined for literary manuscripts as the practice of distinctive scripts is also observable in the documents. Thus, parts of documents written in different scripts are not necessarily due to different hands (Fournet 2008). For example, in the will, which is dated to 634, of Victor, superior of monastery of

St. Phoibammon in the Theban region, the body of the will is written with the sloping majuscule in use in the Coptic documents of the region, while the writing-by the same hand - of the sentence marking the completion of the act (name and position of the scribe, circumstances of the copy) is upright, cursive, and quadrilinear, rather close to that of some contemporary Greek documents (Garel, forthcoming). In the same region, the correspondence of a monk named Frange was discovered. Living in the first half of the eighth century, he was copying manuscripts as part of his activities. In his letters, his writing varies between a slightly sloping and cursive script and an upright one, with well separated letters and diacritical marks similar to those found in literary manuscripts (Boud'hors and Heurtel 2010; Boud'hors 2017). Frange, however, had not been trained to be a notary, since his hand never reaches the cursivity of some administrative documents, such as the ones written by his contemporary Aristophanes, a professional scribe of the neighboring village of Djeme (Cromwell 2010).

\section{Insights on Learning}

Direct information is rare on how scribes were trained and more generally on the learning process of reading and writing. The Theban region, however, provides some insights in this respect. The monk Frange used to call himself a "master." Many exercises written on ostraca found in his hermitage show that he probably taught the basics of writing to 
several disciples or pupils. Judging by the large number of them where the hand resembles his, even though more hesitant, imitation was the basis of learning. Besides, Frange himself seems to have forged his writing by imitating his predecessors in the hermitage (Boud'hors and Heurtel 2010). Things may have been different for professional scribes of the village of Djeme. If the trade often passed from father to son, the scripts of the younger generation often resemble each other, but differ from those of the fathers, which rather suggests the existence of schools (Cromwell 2012).

\section{(p. 631) Between Literature and Document: The Sloping Majuscule of Liturgi- cal Texts}

The sloping majuscule is found in both literary manuscripts and documents. Nevertheless, in the former, it functions primarily as a distinctive script, to copy titles, annotations, and colophons, that is to say, what is not properly literary, but paratextual (Boud'hors 1997). This type of script is also used in the copy of liturgical texts, especially hymns. Since hymns were first copied onto single sheets before being grouped into collections and books, the use of such writing is indicative of their documentary status. A study has recently been conducted on the development of the sloping majuscule in the liturgical texts (Mihálykó 2019, chap. 3). The same kind of consideration could be applied to magical texts.

\section{Bibliography}

Andersen, M., B. Holmen, and J. Tait. 1999. "Palaeographical and Codicological Notes to Supplement Erichsen's Edition of the Copenhagen Fayumic Manuscript of Agathonicus: P. Carlsberg 300." Enchoria 25:1-19.

Boud'hors, A. 1997. "L'onciale penchée en copte et sa survie jusqu'au XV ${ }^{\mathrm{e}}$ siècle en Haute-Égypte." In Scribes et manuscrits du Moyen-Orient, edited by F. Déroche and F. Richard, 117-133. Paris.

Boud'hors, A. 2006. "Paléographie et codicologie coptes: Progrès et perspectives (19962004)." In Huitième congrès international d'études coptes, Paris 2004, vol. 1 : Bilans et perspectives 2000-2004, edited by A. Boud'hors and D. Vaillancourt, 95-109. CBC 15. Paris.

Boud'hors, A. 2008. "Copie et circulation des livres dans la région thébaine $\left(7^{\mathrm{e}}-8^{\mathrm{e}}\right.$ siècles)." In "Et maintenant ce ne sont plus que des villages ...": Thèbes et sa région aux époques hellénistique, romaine et byzantine, edited by A. Delattre and P. Heilporn, 149161. Brussels.

Boud'hors, A. 2017. “Copyist and Scribe: Two Professions for a Single Man? Palaeographical and Linguistic Observations on Some Practices of the Theban Region According to Coptic Texts from the 7th-8th Centuries." In Scribal Repertoires in Egypt from the Old Kingdom to the Early Islamic Period, edited by J. Cromwell and E. Grossman, 274-295. Oxford. 
Boud'hors, A., and C. Heurtel. 2010. Les ostraca coptes de la TT 29: Autour du moine Frangé. Études d'archéologie thébaine 3. Brussels.

Buzi, P. 2015. “Coptic Palaeography.” In Comparative Oriental Manuscript Studies: An Introduction, edited by A. Bausi, P. G. Borbone, F. Briquel-Chatonnet, P. Buzi, J. Gippert, et al., 283-286. Hamburg.

Cavallo, G. 1967. Ricerche sulla maiuscola biblica. Florence.

Cramer, M. 1964. Koptische Paläographie. Wiesbaden.

Cromwell, J. 2010. "Aristophanes son of Johannes: An Eighth-Century Bilingual Scribe? A Study of Graphic Bilingualism." In The Multilingual Experience in Egypt, from the Ptolemies to the Abbasids, edited by A. Papaconstantinou, 221-232. Farnham.

Cromwell, J. 2012. "Following in Father's Footsteps: The Question of Father-Son Scribal Training in Eighth Century Thebes." In Actes du 26e Congrès international de papyrologie. Genève, 16-21 août 2010, edited by P. Schubert, 149-157. Geneva.

Crum, W. E. 1905. Catalogue of the Coptic Manuscripts in the British Museum. London.

Delattre, A. 2007. Papyrus coptes et grecs du monastère d'apa Apollô de Baouît conservés aux Musées royaux d'Art et d'Histoire de Bruxelles. Brussels.

(p. 632) Depuydt, L. 1993. Catalogue of Coptic Manuscripts in the Pierpont Morgan Library. 2 vols. Leuven.

Emmel, S. 1993. "Recent Progress in Coptic Codicology and Paleography (1988-1992).” In Acts of the Fifth International Congress of Coptic Studies, Washington, 12-15 August 1992, Volume 1: Reports on Recent Research, edited by T. Orlandi, 33-50. Rome.

Emmel, S. 1999. "Recent Progress in Coptic Codicology and Palaeography (1992-1996)." In Ägypten und Nubien in spätantiker und christlicher Zeit: Akten des 6. Internationalen Koptologenkongresses, Münster, 20-26. Juli 1996, 2 vols., edited by S. Emmel, M. Krause, S. G. Richter, and S. Schaten, 65-78. SKCO 6. Wiesbaden.

Emmel, S. 2004. Shenoute's Literary Corpus. CSCO 599-600, Subsidia 111-112. Leuven.

Fournet, J.-L. 2008. “P.Stras. V 318 complété: La grande philoponia d’Héracléopolis et les protocoles en cursive inclinée." In Sixty-Five Papyrological Texts Presented to Klaas A. Worp on the Occasion of his 65th Birthday, edited by F. A. J. Hoogendijk and B. P. Muhs, 243-253. PLB 33. Leiden.

Gardner, I., and M. Choat. 2004. "Towards a Palaeography of Fourth Century Documentary Coptic." In Coptic Studies on the Treshold of a New Millennium II: Proceedings of the Seventh International Congress of Coptic Studies, Leiden 2000, edited by M. Immerzeel and J. van der Vliet, 495-503. OLA 133. Leuven. 


\section{Issues and Methodologies in Coptic Palaeography}

Garel, E. Forthcoming. Héritage et transmission dans le monachisme égyptien. Les testaments des supérieurs du topos de Saint-Phoibammon à Thèbes. Cairo.

Gilmore, G., and J. Ray. 2006. "A Fixed Point in Coptic Chronology: The Solar Eclipse of 10 March 601.” ZPE 158:190-192.

Hyvernat, H. (1888) 1972. Album de paléographie copte pour servir à l'introduction paléographique des Actes des Martyrs de l’Égypte Paris. Reprint, Osnabrück.

Irigoin, J. 1959. “L'onciale grecque de type copte.” JÖBG 9:29-51.

Jansma, N. S. H. 1973. Ornements des manuscrits coptes du Monastère Blanc. Groningen.

Kasser, R. 1960. Papyrus Bodmer VI: Livre des Proverbes. CSCO 194-195. Leuven.

Kasser, R. 1991a. “Djinkim.” In Coptic Encyclopedia, 8 vols., edited by A. S. Atiya, 8:111112, New York.

Kasser, R. 1991b. "Paleography." In Coptic Encyclopedia, 8 vols., edited by A. S. Atiya, 8:175-184. New York.

Layton, B. 1985. "Towards a new Coptic Palaeography." In Acts of the Second International Congress of Coptic Studies, Roma, 22-26 September 1980, edited by T. Orlandi and F. Wisse, 149-158. Rome.

Layton, B. 1987. Catalogue of Coptic Literary Manuscripts in the British Library Acquired since the Year 1906. London.

Layton, B. 2000. A Coptic Grammar. Wiesbaden.

MacCoull, L. S. B. 1997. “Dated and Datable Coptic Documentary Hands before A.D. 700.” Le Muséon 110:349-366.

Mihálykó, Á. T. 2019. The Christian Liturgical Papyri: An Introduction. Tübingen.

Nakano, C. 2006. "Indices d'une chronologie relative des manuscrits coptes copiés à Toutôn.” JCoptS 8:147-159.

Orsini, P. 2008. “La maiuscola biblica copta.” Segno e testo 6:121-150.

Orsini, P. 2015. “I papiri Bodmer: Scritture e libri.” Adamantius 21:60-78.

Orsini, P., and W. Clarysse. 2012. "Early New Testament Manuscripts and Their Dates: A Critique of Theological Palaeography." ETL 88(4): 443-474.

Polotsky, H.-J. 1949. “Une question d'orthographe bohaïrique.” BSAC 12:25-35.

(p. 633) Quaegebeur, J. 1982. “De la préhistoire de l'écriture copte.” OLP 13:125-136. 
Satzinger, H. 1991. “Old Coptic.” In Coptic Encyclopedia, 8 vols., edited by A. S. Atiya, 8:169-175. New York.

Stegemann, V. 1936. Koptische Paläographie: 25 Tafeln zur Veranschaulichung der Schreibstile koptischer Schriftdenkmäler auf Papyrus, Pergament und Papier für die Zeit des III.-XIV. Jahrhunderts. Mit einem Versuch einer Stilgeschichte der koptischen Schrift. Heidelberg.

Suciu, A. 2011. "À propos de la datation du manuscrit contenant le Grand Euchologe du Monastère Blanc.” Vigiliae Christianae 65:189-198.

Suciu, A. 2014. "Coptic Scribes and Manuscripts: Dated and Datable Codices from the Monastery of Apa Shenoute, I: The Codices Inscribed by Victor, Son of Shenoute (First Half of the 12th Century." JCoptS 16:195-215.

Torallas Tovar, S. 2016. "Progress in Coptic Palaeography and Codicology (2004-2012)." In Coptic Society, Literature and Religion from Late Antiquity to Modern Times: Proceedings of the Tenth International Congress of Coptic Studies, Rome, September 17th-22th, 2012 and Plenary Reports of the Ninth International Congress of Coptic Studies, Cairo, September 15th-19th, 2008, edited by P. Buzi, A. Camplani, and F. Contardi, 431-456. OLA 247. Leuven.

Vanderheyden, L. 2012. “Les lettres coptes des archives de Dioscore d'Aphrodité.” In Actes du 26e Congrès international de papyrologie, Genève, 16-21 août 2010, edited by P. Schubert, 793-799. Geneva.

Van Lantschoot, A. 1929. Recueil des manuscrits chrétiens d'Égypte, Tome I: Les colophons des manuscrits sahidiques. Leuven.

Zoëga, G. (1810) 1973. Catalogus codicum Copticorum manu scriptorum qui in Museo Borgiano Velitris adservantur. Rome. Reprint avec une introduction historique et des notes bibliographiques par J.-M. Sauget. Hildesheim.

\section{Anne Boud'hors}

Anne Boud'hors is Directrice de recherche at CNRS, Institut de recherche et d'histoire des textes, section Grecque et de l'Orient chrétien, Paris. 